\title{
Continuing the Paul Mission for the Gentiles in the New Era
}

Naomi Sampe ${ }^{1 *}$, Perdi Masuang ${ }^{2}$, Gantina Banne Lembang ${ }^{3}$, Rinus Menok Sara' ${ }^{4}$, Karel Sanda Toding ${ }^{5}$

${ }^{1}$ Postgraduate student of Hoseo University, South Korea,

2,3,4,5 Postgraduate student of IAKN Toraja

*naomisampe@gmail.com

\section{D01: https://doi.org/10.34307/b.v4i2.319}

\begin{abstract}
The research in this paper seeks to find some thought as a product of research that examines the important role of Paul's mission in the early church planting. In addition, this article will examine the pattern of Paul's mission so that church growth is very sporadic. The purpose of this research is to show that Paul's success strategy in mission is very worthy and interesting to be researched and studied, so that it becomes a cornerstone for the church today to continue Paul's mission pattern. Methodology in this research is going to use the theory of Francis Watson which based on the freedom of Paul mission, and also it want to take advantage based on the theory of Terence L. Donaldson that stated the universalism of Paul mission. This research shows that through God's help, Paul succeeded in establishing Gentiles churches. The churches today may learn that the preaching of the Gospel to the new generation today has its own challenges, because the different context. Another thing that today's church needs to learn is that Paul's passion and strategy in his mission has enabled him to build churches for other nations in various places for the glory of Christ.
\end{abstract}

Keywords: gentiles, mission, new era, Paul, today's missionary

Abstrak: Penelitian dalam tulisan ini hendak berupaya menemukan beberapa refleksi sebagai hasil riset yang meneliti tentang peran penting misi Paulus terhadap perintisan gereja perdana. Selain itu, risalah ini hendak meneliti bagaimana pola misi Paulus sehingga pertumbuhan gereja sangat sporadis. Tujuan penelitian ini adalah hendak menunjukkan bahwa strategi keberhasilan Paulus dalam misi sangat layak dan menarik untuk diteliti dan dipelajari, agar menjadi batu penjuru bagi gereja masa kini untuk melanjutkan pola misi Paulus. Teologi misi Paulus yang berkaitan dengan pekerjaan misionaris yang dia layani saat itu. Tulisan ini mencoba menggunakan perspektif Francis Watson tentang kebebasan misi rasul Paulus. Selain itu juga didasarkan pada teori Terence L. Donaldson yang menyatakan tentang universalisme dari misi Paulus. Metodologi dalam penelitian ini akan menggunakan teori Francis Watson yang didasarkan pada kebebasan misi Paulus, serta ingin memanfaatkan teori Terence L. Donaldson yang menyatakan universalisme misi Paulus. Penelitian ini memperlihatkan bahwa melalui pertolongan Tuhan, Paulus berhasil mendirikan gereja-gereja nonYahudi. Manfaat bagi gereja masa kini adalah bahwa Pemberitaan Injil bagi generasi era baru saat ini memiliki tantangan tersendiri karena konteksnya tidak sama lagi dengan era Paulus. Hal lain yang perlu dikaji oleh gereja era masa kini adalah semangat dan strategi Paulus dalam misinya, telah memampukannya membangun gereja-gereja bagi bangsa-bangsa lain untuk kemuliaan Kristus.

Kata Kunci: gereja, masa kini, misi, non-Yahudi, Paulus 
Article History : $\quad$ Received: 05-09-2021 $\quad$ Revised: 30-11-2021

Accepted: 07-12-2021

\section{Introduction}

The Apostle Paul was the greatest Christian missionary of all time. Paul comes to firmly believe that his Gentile mission and apostleship make contribution to the accomplishment of God's original plan for the nations. And his greatest achievement in mission is when the Gospel message of Jesus as the Second/New Adam could be delivered in best way towards all nations.

The Evangelism or mission is the responsibility of every follower of Jesus. This evangelistic mission has become the lifeblood in the history of the church's development. Preaching the gospel to the gentiles began in New Testament times. The most famous Gentiles evangelist in the Bible is Paul. After his encounter with Christ he was transformed from a persecutor of Christ's followers to servants of Christ. He gave his whole life and existence to bring unbelievers to salvation in Jesus Christ. The general goal which underlies Paul's missionary strategy is to establish Messianic houses of worship for people who respond to the gospel and establish Gentile churches wherever the majority of believers are Gentiles. And history proves that he succeeded, it can be seen on the church spread and growth all over the world. The preaching of the gospel for today's gentiles has its own challenges because the context is different from Paul's day. But one thing that needs to be learned is the spirit and strategy of Paul in his mission which made him able to build churches for the gentiles in various places for the glory of Christ.

Paul, however, feels obliged for further to expand his initial understanding of Jesus, in the very process of legitimating the Gentile mission as well as his Gentile apostleship as essential elements of God's salvation plan. Although Paul was a Jews, he was engaged in the Gentiles mission from the beginning. God sent Paul to the Gentiles that means the God accept it among His people and had provided Christ as a power of God to bring salvation for all, Jews and Gentiles. After his conversion, Paul join with Antioch church (the Gentiles church) and solved problem with the Law and circumcision among gentile's church, then the Law and circumcision became an optional. Paul make lineage not by Abrahamic and Mosaic covenant but through Adamic covenant to include the Gentiles into the people of God. Furthermore, Paul go to the basic the Gentiles is a covenant of God who created the world and humankind. Gospel was proclaimed to the Gentiles not through Israel commitment, but through Israel rejection for the Gospel of God's Son.

In Christianity worldview, Jesus is a glory and the light of God that shines upon the nations in which God accomplished the salvation. When Jesus is claimed to be the Lord of the universe, the Lord of the whole cosmos, then He is the Lord of the Gentiles. Paul Mission developed from pulled the Gentiles to requires the ideas of the risen Jesus who 
encounters Paul on the Damascus road at that time Paul acknowledge that the Jesus light should shine among the Gentiles.

This library research is interesting to be studied more deeply, in order to explore and analyze Paul's method of imparting the truth of Christ into believers. The fact is Paul has call by Christ, so the milestone in salvation is in Christ alone. ${ }^{1}$ Paul's encounter with Jesus on the way to Damascus is the starting point of Paul's life transformation.

As Paul did, the mission of the Church today also carries the same noble mission of bringing as many people as possible to accept and enjoy new life with Christ. The gospel of Christ is the answer for those who need a handle in facing the various crises of life. The gentiles of today, desperately need a grip on life to deal with the problems of consumerism, hedonism, the uncertainty of what to believe is, secularism, not knowing the purpose of life, and also the problems of ethical issues. They need light and gospel guidance to guide their lives and make their lives meaningful. Did his true repentance has caused any disconnect between the old life and the new life? Can church today learn from the work such as Paul's ministry, to the various congregations? and to learn the success of his missions among generations at that time?

This article would like to describe that the church is challenged to serve them, but actually all churches already has an example that can be referred, so that all believers in this new era can see the unwavering truth in Christ.

\section{Methodology}

The discussion in this paper uses an explanatory qualitative approach, which explains everything related to the pattern of Paul's mission. In particular, the pattern of his ministry to various congregations and the suitability of his mission for the generation at that time. This research approach wants to explain everything related to Paul's theology of missions which is related to the missionary work he served at that time. This paper is attempt to use the perspective of Francis Watson, that describe that Paul mission was implemented independently, and also the second approach is based on the theory of Terence L. Donaldson that stated the universalism of Paul mission. The Christology centered sprit of Paul was clearly seen in the idea of "adamic to Mesianic" point of view. Second Adam or the new Adam is clearly idea of Paul to spread the Gospel that shows his continuity and discontinuity in his ministry. Furthermore, it is relevant to the challenges of the church's mission for today's congregations. Globally, this study is carried out through theoretical discussions whose sources are literature such as books and journals. This work was supported through focused group discussions by postgraduate students in the mission Theology course at IAKN Toraja, together with inter-college postgraduate

\footnotetext{
${ }^{1}$ Ksenija Magda, Paul's Territoriality and Mission Strategy: Searching for the Geographical Awareness Paradigm Behind Romans (Mohr Siebeck, 2009). 144
} 
students. So, this paper is a result of joint research through student teamwork to complete the final project in the Mission Theology class.

\section{Result and Discussion}

\section{Paul, Christ Apostle for the Gentiles}

The secret background of the calling for Paul is fulfilled through the revelation of his identity, as stated: "Unto me, who am less than the least of all saints, is this grace given, that I should preach among the Gentiles the unsearchable riches of Christ" (Ephesian 3:8). On his way to Damascus to persecute Christians, the risen Jesus appeared to Paul and sent him for prophetic ministry. Paul's conversion and this apostolic calling became a crucial point in his life and theology. On the other hand, the incident on the road to Damascus converted Paul from persecutor for followers of Jesus to the propagator of Christianity. This crucial moment drastically changed Paul's life, thought, theology, and purpose in his life.

After the Damascus event, Paul experienced great enlightenment and changes in his thought. First, As a Jew, Paul is very bound and obedient to the law, but after becoming an apostle of Christ, he declared that Christians have been freed from slavery to the law; Jesus is the end of the law. Second, the function of circumcision under the law was fulfilled in baptism. Through baptism, God's people experience the death and resurrection of Jesus and are united in faith in Jesus. Third, the Gospel that Paul proclaim among the Gentiles is Law free Gospel. Fourth, Paul believes that Jesus' death and resurrection declared that the eschatological time had come.

The most important event in Paul's career as a Christian Gentile apostle is his encounter with the risen Jesus on the Damascus road. This then opens a new light for the church today in expressing its vocation in the midst of the changing times today. For example, in this current era, the question that arises is whether the Covid 19 pandemic can also be seen as the starting point of the church's conversion in carrying out its real mission, so that its services are not trapped in routine worship rites only? The church should return to reflect on the events of Paul's conversion. The church should also try to reach people outside of Christianity (every tribes, Islam, all nations, etc.) just as Paul reached out to Gentiles. This the church needs to do as a manifestation of continuing Paul's mission in this new era.

Between Paul's calling in Damascus and the following first mission in northern Syria and Cilicia, on the one hand, and the beginning of the independent mission of the apostle to the gentiles, on the other, lie about twelve years of activity in Antioch. ${ }^{2}$ Paul's conversion did not only affect the Gentiles. Where through Paul they are called to know

${ }^{2}$ Francis Watson, Paul, Judaism, and the Gentiles: Beyond the New Perspective (Michigan, Cambridge, UK: Wm. B. Eerdmans Publishing, 2007). 83 
Christ. But for me Paul also had an impact on Jews who were obedient to the Law. Through Paul's testimony, King Agrippa said to Paul, "In this short time do you think you will make me a Christian?" Likewise, the church today must design a mission where the mission must be centripetal and centrifugal because in fact people who claim to be Christians do not even guarantee that they have saving faith. It could be that Christianity attached to him is only a formality.

The Damascus event reveals to Paul God's intention to include the Gentiles in his people (Rom 1:5), God's Son as a means of their inclusion, and God's appointment of Paul as the apostle to the Gentiles (Gal 1:16).22) Considering Paul's claim that the ultimate purpose of the revelation of God's Son is "so that I might preach him among the Gentiles," his Gentile mission is a fundamental component of the Damascus experience rather than its later corollary. ${ }^{3}$ Acts takes into account the significant of Paul for the gentile's mission, in that after the Apostolic Council it gives the reader in two large section, (Acts 16:36-19; 21 \& 19:22-28-31).

Furthermore, the impression that Paul now dominates the epoch of worldwide mission all by himself. The present discussion attempts to give a historical and sociological grounding for this view point. Paul oppose Judaism because it is not Christianity.4 Paul as he known as the founding apostle of Christianity, expressly and clearly states the difference with Judaism, which later became a new opportunity for the Gentiles to receive the gift of salvation in Christ (the new Adam). Paul's mission became a new page in his ministry that gave blessings to Generations in this new era to gain access because this second Adam became the gate as well as the core of Paul's gospel message.

Paul himself, were seem as the more responsible missionary throughout the Roman Empire, and it is remarkable that Paul identify himself as the Lord's "light" to the gentiles $^{5}$, as prophesied in Isaiah 49:6. This might suggest that Paul had an unduly high view of himself. This possible misunderstanding is corrected later in the book of Acts where Paul states that the reason Christ himself will proclaim "light" booth to the people of Israel and to the gentiles (Acts 26:23). In other words, the risen Christ was proclaiming the light to the Israel and the gentiles through Paul. It's conclude that Jesus' insistence that his message goes first to the "children" (Israel) and only then to the "dogs" (gentiles) was exactly followed in Peter's preaching (Acts 3:26), and in Paul mission, as reflected in his own letter where the book of Acts quote from the mission sermons of both Peter and Paul. ${ }^{6}$ The light that Jesus brought was destined for Israel as well as for the Gentiles. This means that the focus of Paul's mission is not only to the Gentiles but he must also be on a

\footnotetext{
${ }^{3}$ Terence L. Donaldson, Paul and the Gentiles: Remapping the Apostle's Convictional World (Fortress Press, 1997). 18, 281

${ }^{4}$ Watson, Paul, Judaism, and the Gentiles. 126

${ }^{5} \mathrm{~J}$. Lee Whittington et al., "Legacy Leadership: The Leadership Wisdom of the Apostle Paul," The Leadership Quarterly 16, no. 5 (October 2005): 749-70, https://doi.org/10.1016/j.leaqua.2005.07.006.

6 Paul Barnett, Paul, Missionary of Jesus (Michigan, Cambridge, UK: Wm. B. Eerdmans Publishing, 2008), 122.
} 
mission to the Jews. Likewise with the focus of missions in this new era, our mission is not only focused on people who are not yet Christians, but missions must also be started in our community, both in the church and other Christian communities.

The Gospels of Matthew, Luke, the Acts, and even the letters of Paul proclaim the risen Christ as the center of preaching and evangelizing spirit for all nations. Then the barrier was opened for all peoples, nations and languages to believe in the message of salvation through Paul's mission. In other words, Paul's mission is now become an important milestone for the church (as a new Israel) to continue the spirit and motive of Paul's mission, to retell to all nations that Christ is risen.

He is convinced that as all mankind is the first descendant of Adam to inherit Adam's sin, so all humankind is the inheritor of penance and salvation through the Second Adam, Jesus Christ. As people who know Christ of course we need to admit that we have been redeemed from the sins that were previously inherited from the first Adam. Through the sacrifice of the second Adam on the cross our sins were paid for. Then what about those who do not know the second Adam? Of course there must be an approach that we must use to open their horizons of thinking because at this time there are religions and even a group of people who do not believe in inherited sin.

Therefore, it is his duty as an apostle of Jesus Christ to introduce these Gentiles to the love of Jesus. It was this redemptive work of Jesus that became the center of Paul's ministry to the Gentiles. Jesus, is the second Adam, so through His salvation work everyone finds the way to the Father. It is through Christ, that everyone who believes in Him should become the child of the most High God, and then obtain the status to heir the Kingdom of God.

Paul comes to firmly believe that his Gentile mission and apostleship make contribution to the accomplishment of God's original plan for the nations and his Gospel message of Jesus as the Second/New Adam best explains God's plan for the nations. Paul realized that everyone including the Gentiles was loved by God, therefore he had to preach deliverance for them. The responsibility to preach the gospel and convey salvation in Jesus Christ/second Adam, is not only Paul's responsibility but the responsibility of every believer (church) at this time. This needs to be done to continue the missionary work that Paul had built in his day. An understanding like that of Paul needs to be shared by all believers today, so that they are able to continue the mission of preaching the gospel that Paul had built before. Of course we have to use the missionary approach which was also applied by Paul.

What kind of approach did Paul use? Paul has many strategies/approaches, including individual, group approaches, using citizenship status and others. We can also use this approach in the context of our lives today. 
Jesus as the new Adam, is a new culmination (discontinuity and continuity) to explain anew and inform God's greatest work for all mankind. The work of God's love is seen perfectly in the sacrificial work of Jesus Christ on the cross.

\section{Paul Mission Goals and Strategy}

First, at the beginning of that year, Paul and his colleagues sought to visit all the scattered houses of worship throughout the Roman Empire, starting from Asia Minor. Because the gospel "is for the Jews first" (Rm. 1:16). After that, he developed a missionary journey which he realized was his main apostolic calling to give the gospel of Jesus Christ to nonJews or commonly called Gentiles by the Jews.

Paul's missionary strategy is to establish Gentile churches wherever the majority of believers are Gentiles. We must keep in mind that the era of Christianity in the first century was the greatness of the century of Jewish missionary activity to both Jews and Gentiles. $^{7}$

In those days, almost all Jewish houses of worship had new non-Jewish followers and "people who feared God". Gentile men and women who have been freed from idol worship and have been drawn to Jewish ethical monotheism. Paul knew that it was in these houses of worship that he witnessed evidence of God's early work among the Gentiles. Only in houses of worship could he establish good relations with Jews and Gentiles.

When the Jewish community of worship in a place rejects the news outright, he then turns his attention to the Jews and Gentiles who want to accept the Gospel he preaches, as happened in Antioch and Pisidia where the Jews reject it. "Indeed, the word of God must be preached to you first, but you reject it and consider yourself unfit to have eternal life. Therefore, we turn to other nations. For this is what we were commanded to say:" I have appointed you to be a light to nations that do not know God, that you may bring salvation to the ends of the earth "(Acts 13: 46-47).

Inevitably Paul was determined to win the spiritual hunger of these Gentiles to believe in Jesus and make them the forerunner of the Greek-speaking congregation from the rise of the early Christian church.

To achieve the above results Paul certainly uses strategy in his missionary journey. ${ }^{8}$ He devised his missionary strategy to the Gentiles meticulously and fully surrendering to Jesus Christ to reach the greatest number of Gentiles who were hungry and thirsty for the love and salvation of Jesus Christ, with the highest efficiency. First of all, even though he did not neglect the Jewish nation at all, his calling was to introduce

7 Hollis Read, The Hand of God in History, Or, Divine Providence Historically Illustrated in the Extension and Establishment of Christianity (Connecticut: H. Huntington, 1849). 353

8 "Paul the Missionary - Oxford Handbooks," oxfordhandbooks, 2019, https://www.oxfordhandbooks.com/view/10.1093/oxfordhb/9780199600489.001.0001/oxfordhb9780199600489-e-13. 
Jesus, the last and perfect Adam to all the descendants of Adam called infidels, to deliver them from the curse of sin, for a new life in the kingdom of God.

Paul has many strategies, including individual, group approaches, using citizenship status and others. Paul uses everything he has by relying on the help of the Holy Spirit. ${ }^{9}$ Paul tried his best to preach the Gospel in areas where the preaching of the gospel had never happened or had not been reached by the students and other apostles (II Corinthians 10:16), Paul said that "not where Christ was known, so I don't build on other people's foundations", (Rm. 15:20)

Paul missionary strategy and his conceptions of the gentiles' mission was founded on Paul understanding of his mission is integral to his self-understanding and though as a whole. The strategy he pursued in his missionary endeavor shows that he saw himself in global task. He plans and "work within the framework of whole provinces: Syria and Cilicia, Asia, Macedonia, Achaea, Illyricum. He concentrates "his own personal work especially on provincial capitals: Thessalonica, Corinth and Ephesus.

Paul's mission concentration was first directed at large cities, especially cities in large port areas. Paul himself grew up and worked in the big city, Tarsus himself, so he already knew and was familiar with the problems of life in the big city. He then preached in major capitals such as Rome and at the center of world culture, Athens. Furthermore, Philippi was the main city of Macedonia (Acts 16:12), as were Corinthians in Achaia and Ephesus in Asia Minor. While Antioch, Troas and Thessalonica were large and bustling port cities. The effort to build a solid church in such cities is very visionary and has the potential to be the center of a mission to bring the gospel to the whole world.

Broadly speaking, mission services for Gentiles in these large cities also reach people who have special abilities or certain positions to teach and influence others. These influential people included such philosophers and clever in Athens, the governor of Sergius in Paphos, respected upper-class women of Berea, the Tyrannus school community in Ephesus, and many others. They spread the influence of the gospel among Gentiles, so that more and more people accepted Christ and gave themselves to be baptized.

\section{From Adamic to Messianic}

Adam (means: human) was the first human being to be a reflection of all humakind, falling because of disobedience, resulting in sin and death for all human beings. Death that entered into the world because of the disobedience of one person has now controlled humans and the world, so that no one escaped sin or death. Therefore, just as sin entered into the world by one person, and by sin is also death, so death has spread to all people,

${ }^{9}$ C. Peter Wagner, Strategies for Church Growth: Tools for Effective Mission and Evangelism (Oregon: Wipf and Stock Publishers, 2010). 48, 180, 119 
because all have sinned (Romans 5:12). Therefore here Paul links sin with human disobedience. Therefore everyone need freed from $\sin$. The context of $\sin$ is not only sin but in that sinful state, humans have lost the glory of God, while humans are meaningless at all without the glory of God. This is where God's love appears to all mankind of Adam's descendants and heirs of Adam's sin by sending his only Son into the human context to lift man from the mud of sin.

Paul emphasized Jesus' obedience in living the Father's will until he gave His life on the cross. Christ's obedience has brought all humans to the grace and grace of God. Because if by one person's offense all people have fallen into the power of death, even greater is the grace of God and His gift which He bestows upon all because of one person, namely Jesus Christ. (Rm. 5:17) Paul's theology presents a high picture with respect to the theology of God, Paul describes God as sovereign, and self-revealing. Through grace in Jesus Christ through that grace God's purpose from eternity has been revealed now. The church today needs to understand multiplicity and realize that God's grace was not balanced with the transgression of Adam which resulted in all human beings falling into sin and resulting in judgment for many, but grace through one person, namely Jesus Christ, resulted in the justification of all people. The obedience to Christ brought man into a true life and justification in Him. Therefore, just as by one violation all people receive condemnation, so also by one righteous act all people get justification for life. As just as by one man's disobedience everyone has become a sinner, so too by one man's obedience everyone becomes righteous (Rm. 5:18).

Paul did not simply align Adam's disobedience with Christ's obedience. For him, the two things are not balanced. Therefore, Paul said, "Where sin abounded, grace abounded abundantly." Here Paul asserts that God's grace is far greater and more powerful than sin and death. And where sin abounded, grace abounded abundantly, so that, just as sin reigns in death, grace will rule by righteousness for eternal life, by Jesus Christ, our Lord (Rms 5: 20b-21).

Paul observes the emergence and growth of the transformed Gentile community as a result of the transformative work by the eschatological Spirit, which manifests their Lord Jesus' powerful presence among them. With the presence of Jesus Christ, the exclusivism on salvation that previously only applied to Jews have now been removed, for God alone is pleased to grant salvation on His great mercy and love trough Jesus Christ, and also through the fullness of the Holy Spirit. God's saving work is universal (Rom. 10:12). In his defense of the new Gentile community, Paul does not pursue intellectual arguments about an abstract doctrine.

Adam Christology position is an intermediate step between elevated Christology and gentiles' mission (Adam also identified as the image of God). But while fully recognizing the Adam overtones in Paul image of God language, the links attempts to forge between Paul bright vision itself, the divine glory and the term "image of God" are tenuous 
indeed. Further, Adam Christology, rather than being an essential step it is function more as an alternative way of stating the universalism following from the elevate Christology itself. ${ }^{10}$

Paul understood his gentiles' mission as a means of hastening the arrival of the messianic age. In any case, in messianic expectation, universal lordship in no way stands intention with the particularism of covenantal nomism, indeed, it serves to reinforce it. In this case Paul introduces the testimony of his encounter with Jesus that made him repent. Here, Paul is responding to the Jews holding fast to the Law, and this way of responding has nothing to do with hastening the coming of the Messiah.

The mean of salvation itself, which appear in Rome 1:16, is the Jew and gentile distinction does come into view with the connection with the Gospel, the point is that the Gospel bears on each equally. The Gospel "the power of God for salvation for everyone who believes". Paul apparently believed that the opportunity of salvation for the gentiles would come to an end with the Parousia. Salvation is a grace that is not the result of human struggle but because of God's own grace. This in clearly implied the salvation of Israel would take place once the gentile mission has been brought to fulfillment that is completed. ${ }^{11}$

Paul engages in more direct Christological application of scripture in Rome 10:69, Paul glosses the text of Deuteronomy 30:11-14 in various ways to introduce a strongly Christological reading. However, Paul invokes scriptural support for his messianic claims. In Romans 5, his Adam Christology refers to the fallen state of Adam prior to the revelation of Torah, in order to equate the restoration with a new Adamic figure who is identified as the one man, Jesus Christ (Rom. 5:15). Here the technique that is employed depends upon the perceived typological fulfilment or completion of what are seen by Paul as stories or soteriological events that were lacing their ending until they found messianic fulfilment in Christ. 12

\section{Implementation of Paul missionary method in Today's Missionary}

Contextualization is a way of conveying the gospel of Jesus Christ in certain cultures in accordance with the context of today with the seriousness as the Apostle Paul. Now, it can be said that gentiles are spread from cyberspace to the corners of the world. Those are the generation of the new era. They all need to be reached to be part of God's children who inherit eternal life in Jesus Christ.

Churches and the today's evangelists can emulate the integrity and method of mission of the Apostle Paul. As it proven that Paul's integrity and evangelistic methods

\footnotetext{
10 Donaldson, Paul and the Gentiles. 282

11 Donaldson. 188

12 Michael F. Bird and Joel Willitts, Paul and the Gospels: Christology's, Conflicts and Convergences (London and New York: A \& C Black, 2013). 90
} 
cannot be separated. Integrity is most important thing to emphasize the gospel message when it delivered and spread. The gospel of salvation of Jesus Christ is not just words, but must be real in deeds. The Holy Spirit strengthens each evangelist to be a living example.

Although the strategy Paul used to be different from the situation today, there are several evangelistic principles that can be drawn and used today, such as: First, Gospel preaching is carried out in the city, big cities especially in public and strategic places, then establish relationships with people who are found at the place, preaching the gospel little by little. Places that have been reached with the mission of Christ's evangelism must be the center of evangelism as Paul founded the city church.

Second, he established the church of Christ in strategic big cities like Philippi and Ephesus. Furthermore, the Church supports the ministry of evangelism to new places that are not yet reached by the gospel. Paul continued to establish communication with the Church who had received the gospel by writing a letter. This means that there must be a follow-up of the church or people who have been introduced to the gospel of Christ so that they too experience the strength and firmness of the faith. (Acts 19: 9). Thrid, Look for and understand the worldview of the local culture being evangelized especially about their beliefs. That way the evangelist can then enter the gospel message from the worldview. Paul conducts cross-cultural evangelism. To avoid miss communication (misunderstanding) due to worldview differences such as events in Lystra (Acts 14: 8-18). Worldview is a world / world view, or underlying assumptions or actions that underlie a culture (eg. Acts 17).

Four, The God that Paul preached was the God who created and invited all human beings including those who were speaking in the gospel that was delivered. The heart of the gospel is Jesus who died and rose for everyone. Thus, hurting Christ. Five, use something that is familiar to them to understand the gospel easily. Paul uses the term tent to explain understanding, the Stoic principles and epicureans to explain God the Creator and His judgment. This invites the attention and sympathy of the listener. He proved the views and beliefs of his listeners to explain the subject of Christianity, so that it helped open the gospel to people who could not believe in the Bible. Six, live among evangelized locals. Follow local regulations and culture so that local people can accept it so they have the opportunity to preach the gospel and express God's love through Jesus Christ for them.

\section{Conclusion}

Paul Mission for Gentiles in all nations, shows us the historical continuity of God's love for mankind. Despite Adam's rebellion to God and his fall into sin with all his offspring indeed aroused God's wrath but never stopped God's loyal love for mankind. God prepared the second Adam to make up for the failure of the first Adam. God does not want mankind to His creation to perish. Jesus Christ the second Adam, obediently through suffering, death and finally resurrected to predict death and bring salvation and eternal life to those who 
believe in it. How precious humankind is in the eyes of God and Jesus Christ, today Paul realizes that everyone including Gentiles is loved by God, therefore He must preach their deliverance of sin and eternal salvation. So that people who do not know and do not yet believe in the grace and glory of life in Jesus can believe in Jesus, be redeemed, enjoy life with Christ, be raised up and have eternal life in the kingdom of God.

The responsibility to preach the gospel and deliver salvation in Jesus Christ is not only the responsibility of Paul but the responsibility of every believer especially of every Disciples of Christ who have learned and know and believe in salvation and deliverance in Jesus Christ. The task of Jesus' followers is to make all nations His disciples, baptize them and teach them. A disciple of Christ constantly identify yourself with Christ and be willing to die for God. Jesus wants to have students from every ethnic group (Matthew 28: 18-20). Jesus Mission Concept Christ in Matthew 28: 18-20 is a mission statement coming out of Jesus Christ who known as The Great Commission. So, the concept of mission in the Gospel of Matthew is Jesus Christ's own concept of bringing all peoples to power The Messiah owns all power on earth and in heaven. Paul says "For when I preach the gospel, I cannot boast, since I am compelled to preach. Woe to me if I do not preach the gospel!"(1 Corinth. 9:16). The Holy Spirit is the power that the Lord Jesus promised his disciples before being lifted up in glory to heaven to empower believers spread God's love through Jesus Christ to all the descendants of Adam so that they may believe in Christ, accept penance, live a new life, die and be resurrected to obtain eternal life and glory in the Kingdom of God.

Paul's (Saul) encounter with Jesus on the way to Damascus is the starting point of Paul's life transformation. In this case, even though Paul/Saul has a blessings in shift of paradigm: yet Paul did not completely abandon his old life, but had a new understanding of the scriptures by looking at it from the perspective of the Risen Christ. Everything must be seen in the center of Christ. His theological construction from Adamic to Messianic, can help reader's projection the continuity of ideas and the reality of Paul's ministry in mission. The church today can learn that mission begins with an encounter with Jesus, and initiative always comes from God. This calling from God is the starting point for the church's mission to deliver the message of salvation to generations in this new era.

\section{Referensi}

Barnett, Paul. Paul, Missionary of Jesus. Michigan, Cambridge, UK: Wm. B. Eerdmans Publishing, 2008.

Bird, Michael F., and Joel Willitts. Paul and the Gospels: Christologies, Conflicts and Convergences. London and New York: A\&C Black, 2013.

Donaldson, Terence L. Paul and the Gentiles: Remapping the Apostle's Convictional World. Fortress Press, 1997. 
Magda, Ksenija. Paul's Territoriality and Mission Strategy: Searching for the Geographical Awareness Paradigm Behind Romans. Mohr Siebeck, 2009.

oxfordhandbooks. "Paul the Missionary - Oxford Handbooks," 2019. https://www.oxfordhandbooks.com/view/10.1093/oxfordhb/9780199600489. 001.0001/oxfordhb-9780199600489-e-13.

Read, Hollis. The Hand of God in History, Or, Divine Providence Historically Illustrated in the Extension and Establishment of Christianity. Connecticut: H. Huntington, 1849.

Wagner, C. Peter. Strategies for Church Growth: Tools for Effective Mission and Evangelism. Oregon: Wipf and Stock Publishers, 2010.

Watson, Francis. Paul, Judaism, and the Gentiles: Beyond the New Perspective. Michigan, Cambridge, UK: Wm. B. Eerdmans Publishing, 2007.

Whittington, J. Lee, Tricia M. Pitts, Woody V. Kageler, and Vicki L. Goodwin. "Legacy Leadership: The Leadership Wisdom of the Apostle Paul." The Leadership Quarterly 16, no. 5 (October 2005): 749-70. https://doi.org/10.1016/j.leaqua.2005.07.006. 